\title{
Evolução e estrutura diferenciadas dos segmentos da indústria de papéis no Brasil - 1980 a 2010
}

\author{
Adriana Estela Sanjuan Montebello* \\ Carlos José Caetano Bacha*
}

\begin{abstract}
Resumo
O objetivo deste trabalho é analisar, no período de 1980 a 2010, as evoluções e estruturas distintas dos segmentos que compõem a indústria de papéis no Brasil. Além disso, pretende-se valorar os elos da subcadeia de papéis de imprimir e escrever. A pesquisa utiliza dados secundários coletados nas seguintes fontes: Associação Brasileira de Celulose e Papel (Bracelpa), Food and Agriculture Organization (FAO), Ministério do Desenvolvimento, Indústria e Comércio Exterior (MDIC) e Grupo Economia Florestal Cepea Esalq-USP. Os resultados gerados permitem constatar diferenças entre os segmentos de uma indústria e, com isso, sugere que as políticas e estratégias industriais devem não apenas ser diferenciadas por indústria, mas também considerar as diferenças internas a cada indústria.
\end{abstract}

Palavras-chave: Indústria de papéis no Brasil. Organização industrial. Cadeia de valor.

* Doutora em Economia Aplicada pela Esalq-USP. Professora do Departamento de Tecnologia Agroindustrial e Socioeconomia Rural da UFSCar. E-mail: adrianaesm@cca.ufscar.br

** Pós-doutorado pela University of Illinois at Urbana-Champaign. Professor titular do Departamento de Economia, Administração e Sociologia da Esalq-USP. E-mail: carlosbacha@usp.br 


\section{Introdução}

O papel é um dos produtos mais consumidos no mundo e, há séculos, faz parte do cotidiano da humanidade. O papel era considerado, até o século passado, o principal instrumento para a difusão da escrita e da informação, além de ter muitas aplicações na vida humana, a exemplo, segundo informe da Associação Brasileira de Celulose e Papel - Bracelpa ${ }^{1}$, das caixas para transporte de mercadorias, das embalagens que protegem alimentos e centenas de outros produtos, que vão desde folhas para impressão até uma variedade de produtos para higiene e limpeza.

Segundo informações da Bracelpa (2010), o papel foi criado na China há cerca de 2 mil anos, quando se misturavam cascas de árvores e trapos de tecidos, que, após molhados, eram batidos até formar uma pasta, depois de seca, essa mistura transformava-se em uma folha de papel. Atualmente, a maior parte dos papéis é feita com fibras de árvores. No caso do Brasil, o eucalipto é a espécie arbórea mais utilizada devido ao seu rápido crescimento. De acordo com Montebello e Videira (2006), as fibras de eucalipto permitem gerar celulose, ${ }^{2}$ que é utilizada na confecção de papéis de baixa resistência ao rasgo, como os de imprimir e escrever, cartões e sanitários. Os mais variados tipos de papéis são classificados em seis categorias, de acordo com sua finalidade, a saber: imprensa, imprimir e escrever, embalagem, tissue (para fins sanitários), cartão e outros fins (esse último não será analisado neste artigo).

Apesar de tanto a produção quanto o consumo de papéis estarem concentrados nos países mais desenvolvidos, de acordo com dados da Bracelpa, ${ }^{3}$ o Brasil vem se posicionando como um importante produtor de papel, em especial de embalagem, de imprimir e escrever e de papel-cartão. De 2002 a 2012, o país aumentou sua produção em $27 \%$, com crescimento médio de $2,7 \%$ ao ano, acompanhando as mudanças da economia brasileira.

O desenvolvimento socioeconômico e o aumento de renda da população, com a inserção de novos consumidores no mercado, resultaram em mais demanda por livros, cadernos, jornais e revistas, embalagens para alimentos, remédios e itens de higiene pessoal. No ranking dos maiores produtores, o Brasil posicionou-se como $11^{\circ}$ em 2009, com a produção de 9,43 milhões de toneladas do produto. É importante destacar que o Brasil conta com as vantagens competitivas na produção de celulose, que é a matéria-prima primordial para elaborar papéis.

O papel brasileiro é fabricado a partir de madeira oriunda de florestas plantadas (o que atende às pressões ambientais) e produzido a custos decrescentes até meados dos anos 2000 (MONTEBELLO, 2006), fruto das pesquisas e inovações 
tecnológicas no setor de celulose e papel. ${ }^{4}$ Como país exportador, o Brasil ocupa a $15^{\mathrm{a}}$ posição, e a $21^{\mathrm{a}}$ posição como país maior importador de papéis. Em 2009 , foram exportados 1,84 milhão de toneladas de papéis, segundo informações da Bracelpa (2010), ou seja, $20 \%$ da produção de papéis teve como destino o mercado externo. Nesse mesmo período, o consumo próprio das empresas de papéis representou $26 \%$ da produção brasileira. Assim, nota-se que a indústria de papéis no Brasil está direcionada para o mercado interno ( $54 \%$ de sua produção).

Entretanto, é importante destacar que, dentro da indústria de papéis no Brasil, há evoluções e comportamentos distintos entre os seus segmentos, uma vez que eles apresentam grau de concentração, barreiras à entrada (como a decisão pela integração vertical), quantidade e distribuição das firmas diferentes entre esses segmentos e, consequentemente, o comportamento ou a política estratégica de seus preços podem ser diferentes. Assim, uma análise geral da indústria de papéis no Brasil como um todo, sem considerar as particularidades dos seus segmentos, não permite aos formuladores de políticas públicas e aos grupos empresariais definirem políticas e estratégias que permitam aumentar o desenvolvimento e a competitividade dessa indústria.

Há uma ampla literatura analisando o setor de celulose e papel no Brasil. Por exemplo, Sande (2002), International Labour Organization (ILO) (2001), Daura (2004), Ouchi (2006) e Montebello (2010). Os trabalhos que analisam a indústria de papéis no Brasil são, no entanto, em menor número e podem ser agrupados da seguinte forma: (a) trabalhos analisando a organização da indústria de papéis no Brasil (CARRAZZA; BACHA, 2004, SILVA, 2002); (b) trabalhos analisando o papel das políticas públicas de estímulo à indústria de papéis no Brasil (SILVA, 2002); (c) trabalhos analisando a subcadeia de papéis de imprimir e escrever sob o enfoque da cadeia de valor (SILVA, 2003; ARANHA, 2010).

Os trabalhos de Sande (2002) e ILO (2001) mostraram como as mudanças geradas pelo processo de globalização afetaram o setor de celulose e papel no contexto mundial. Sande (2002) destacou que os efeitos da globalização sobre as empresas do setor florestal podem ser observados pelo aumento das fusões e aquisições entre as empresas, como forma de ganhar competitividade no mercado internacional, pela adoção de novas tecnologias e diversificação de produtos e pela preocupação com as questões de certificação florestal. Além disso, o autor destaca que essas mudanças produzidas pela globalização econômica causaram diferenças dentro do setor florestal, isto é, entre as indústrias que compõem esse setor. Já o trabalho da ILO (2001) destacou o aumento das pressões econômicas e ambientais gerado pelo processo de globalização das economias sobre todos os subsetores do setor florestal, 
como: florestas, indústrias de madeira e indústrias de celulose e de papel. Esse estudo, que abrangeu os países da Europa, América e Ásia, também identificou outros reflexos do cenário da globalização sobre esse setor: o aumento do comércio de produtos florestais, a entrada de novos países como exportadores e importadores desses produtos e o papel do capital estrangeiro e das companhias transnacionais nas indústrias de base florestal. Além disso, mais especificamente para as indústrias de papel e celulose inseridas no comércio internacional, os desenvolvimentos tecnológicos e as vultuosas economias de escala, acompanhadas de fusões e aquisições, aumentaram o grau de concentração das indústrias em quase todos os países, de forma a ganharem competitividade dentro do mercado mundial.

Os trabalhos de Daura (2004) e Ouchi (2006) analisaram as mudanças derivadas do processo de globalização sobre o setor de celulose e papel no Brasil. Segundo Daura (2004), a partir dos anos de 1990, as produções de celulose e papel apresentaram crescimento, enquanto que o número de mão de obra empregada nessas indústrias apresentou constante queda, refletindo uma nova estrutura produtiva e organizacional, com uma tendência acentuada na redução de trabalhadores com baixa escolaridade e consequente aumento do uso da mão de obra qualificada. Também, Daura (2004) destaca que houve um novo padrão de flexibilidade vinculado a um novo regime organizacional do trabalho denominado pós-fordismo, ${ }^{5}$ que nos anos 1980 tem um caráter mais restrito. Contudo, nos anos de 1990 pode-se dizer que ocorreu uma mudança na forma de organização do trabalho no setor de celulose e papel. Assim, essa nova forma de organização da estrutura industrial do setor de celulose e papel esteve vinculada aos padrões pós-fordista. Dentro desse setor, foi possível implementar uma administração com cortes de trabalhadores e ampliação das terceirizações. A autora concluiu ainda que os elementos da globalização estiveram presentes no setor de celulose e papel brasileiro nos anos de 1990, tanto em suas estratégias produtivas (melhoria da qualidade, redução de custo das matérias-primas e desenvolvimento de produtos e equipamento, com ganhos de escala) quanto em suas estratégias de mercado (integração da cadeia produtiva, busca de produtos de maior valor agregado e consolidação patrimonial).

Já o estudo de Ouchi (2006) deu ênfase às pressões ambientais sofridas pelas empresas líderes no setor de celulose como forma de analisar como elas se posicionam diante dessas pressões. Por meio de um estudo qualitativo, baseado em entrevistas realizadas entre maio de 2005 e janeiro de 2006, com executivos das principais empresas líderes no setor, Aracruz Celulose, Celulose Nipo-brasileira (Cenibra), Klabin, Suzano Papel e Celulose e Votorantim Celulose e Papel (VCP), Ouchi (2006), avaliou os aspectos de sustentabilidade corporativa, isto é, 
a sustentabilidade nas empresas líderes do setor de celulose e papel, de forma a entender como as grandes empresas estão se posicionando em relação ao tema em questão e como elas podem estabelecer melhores práticas frente às pressões ambientais trazidas como o processo de liberalização econômica entre os países.

Entre seus resultados, o autor destaca que a busca pela sustentabilidade corporativa no setor de celulose e papel apresenta-se como uma tendência diante da inserção desse setor no mundo globalizado, uma vez que tal setor está ligado a uma atividade produtiva dependente de recursos naturais com grande potencial de impacto no meio ambiente e com longos ciclos de produção, frutos de investimentos de longo prazo de maturação. Ouchi destaca ainda que o plantio das florestas pode impactar o meio ambiente de forma positiva ou negativa.

Quando realizado de forma inadequada, o plantio das florestas pode acarretar assoreamento e contaminação de rios, além da extinção de animais e a consequente redução da biodiversidade da região de plantio. De outro modo, quando bem planejado e gerido, o plantio de florestas para fins de produção de celulose, juntamente com a preservação de florestas nativas (gerando mosaicos florestais), pode aumentar a biodiversidade do local, além de proteger os recursos hídricos e incentivar a conscientização da população local para a preservação da natureza. No caso da produção industrial, o autor descreve o envolvimento de uma série de questões ambientais, tais como a emissão de odores e efluentes, além da utilização de produtos químicos nocivos à saúde, como o cloro. Essas questões são fundamentais na análise da sustentabilidade, uma vez que podem causar relevantes impactos e gerar grandes passivos ambientais nas empresas do setor.

O trabalho de Carraza e Bacha (2004), assim como o de Silva (2002), teve como objetivo estudar a estrutura da indústria brasileira de papéis no Brasil. Os autores analisaram a evolução, a estrutura e os desafios da indústria de papéis no Brasil, pautando-se por avaliar os diferentes segmentos dessa indústria: papéis de imprimir/escrever, embalagens, cartão/cartolina, sanitários, imprensa e papéis especiais. Os autores concluíram que a indústria de papéis apresenta evoluções e concentrações diferenciadas segundo os segmentos produtores de papel e mesmo dentro de cada segmento há concentração diferenciada por tipos de papéis.

Além disso, a produção da indústria brasileira de papéis concentra-se em dois segmentos, a saber: papéis de embalagem e papéis de imprimir e escrever, e em poucos tipos de papéis dentro desses dois segmentos, tais como os papéis-offset, couché e papelão ondulado (capa de $1^{\mathrm{a}}$, miolo e capa de $2^{\mathrm{a}}$ ). De acordo com Carraza e Bacha (2004), a análise de cada segmento mostrou que os mais concentrados, em ordem decrescente, são: papel-imprensa, papéis de imprimir/escrever, papéis 
especiais, papéis de embalagem, papel-cartão e papéis para fins sanitários (tissue). Já na análise por tipos de papéis dentro de cada segmento, o estudo em análise observou que os índices de concentração são mais altos, principalmente para os papéis do tipo offset, couché e apergaminhado do segmento de imprimir e escrever; do tipo capa de $2^{\text {a }}$ e kraft natural para sacos multifolheados do segmento de embalagens, no qual o índice de concentração (CR4) é maior do que $75 \%$.

Silva (2002) também analisou a formação da oferta da indústria brasileira de papel pelos seus segmentos. Segundo o autor, o segmento produtor de papéis de embalagem é o mais importante para a indústria de papel, tanto em termos de produção quanto em número de firmas. Entretanto, o fato de esse segmento contar com grande número de firmas reflete a desconcentração do mercado e a estrutura relativamente mais competitiva do mercado. Já no caso do segmento produtor de papéis de imprimir e escrever, o autor concluiu que ele é muito mais concentrado, já que apenas quatro firmas controlavam $80 \%$ da produção e respondiam pela totalidade das exportações desse tipo de papel no final dos anos 1990. No segmento produtor de papéis-cartão e cartolina, o autor mostra que as empresas que participam desse segmento são as mesmas que participam do segmento produtor de papéis de imprimir e escrever e diversificam a produção para elaborar papel-cartão e cartolina. O segmento produtor de papéis-sanitários mostrou baixa concentração nesse estudo, sendo, normalmente, uma alternativa de diversificação das firmas líderes do segmento produtor de papéis de embalagens. Já o segmento produtor de papéis especiais apresenta alta concentração, pois uma pequena parcela do mercado dedica sua produção para esse tipo de papel. Por fim, o trabalho destacou que o segmento mais concentrado é o de papel-imprensa, pela existência de apenas uma empresa operando nesse segmento. Entretanto, foi destacado que essa concentração não se reflete no poder de mercado dessa empresa, pois a capacidade produtiva dessa firma é insuficiente para atender o mercado doméstico, o que estimula a entrada de produtos importados e dificulta a competição nesse segmento.

O papel das políticas públicas em estimular a indústria de papel no Brasil foi ressaltado na pesquisa de Silva (2002), com ênfase no segmento produtor de papéis de imprimir e escrever. Segundo o autor, esse segmento se desenvolveu, principalmente, a partir da década de 1960, e o Estado teve um papel decisivo no desenvolvimento da indústria de papéis, e do segmento mencionado em particular, por meio de financiamentos e programas governamentais especiais, por considerar tal produto essencial para o desenvolvimento da economia brasileira. Além disso, o incentivo à indústria de papel deu-se pelas vantagens absolutas fundamentadas na tecnologia de uso do eucalipto como fonte alternativa de fibra. 
Na década de 1970, Silva (2002) relata que os projetos aprovados pelo Banco Nacional de Desenvolvimento Econômico, atual Banco Nacional de Desenvolvimento Econômico e Social (BNDES), para a indústria de papel aumentaram significativamente. Em 1977, lançou-se o I Programa Nacional de Papel e Celulose (I PNPC) cujo objetivo era alcançar a autossuficiência em ambos produtos (papel e celulose) e promover a inserção no mercado internacional de celulose. Tal objetivo foi alcançado e, na década de 1980, o Brasil surgiu como exportador de papéis de imprimir e escrever. Nesse ambiente de vendas externas, criou-se, em 1987, o II Plano Nacional de Papel e Celulose (II PNPC), que visava repassar recursos, por meio do BNDES, para duplicar a capacidade de produção até 1995. Contudo, Silva (2002) ressalta que no início dos anos 2000 houve o decréscimo das exportações brasileiras nesse segmento devido ao redirecionamento da produção para o mercado interno, e não pela redução da competitividade da indústria local no mercado externo.

O trabalho de Silva (2003) analisou, comparativamente, as principais empresas exportadoras mundiais e brasileiras e os fatores determinantes da competitividade da indústria de papel de imprimir e escrever sob a ótica da cadeia de valor. Por meio de uma pesquisa de campo com os principais agentes econômicos envolvidos na exportação desse produto no Brasil e utilizando o ferramental teórico da cadeia de valor, Silva (2003) observou que as empresas brasileiras têm vantagens competitivas na etapa de recursos florestais (domínio da matéria-prima, inovação e integração na silvicultura), porém produzem produtos com baixo valor agregado e possuem baixa capacidade de controle dos preços exportados.

O trabalho de Aranha (2010) usou o conceito de cadeia de valor para diagnosticar que elo do segmento produtor de papéis de imprimir e escrever mais agrega valor. Tomando o mês de setembro de 2010 como referência, a autora constatou que $53 \%$ do preço pago pelo consumidor pela tonelada de papel cut size foram agregados na indústria que elabora esse produto, $23 \%$ na fábrica de celulose e outros insumos, $12 \%$ na distribuidora e $11 \%$ no varejo. Trata-se de trabalho inicial sobre o tema e que apenas considerou um mês.

O presente estudo distingue-se dos trabalhos encontrados na literatura, pois pretende diferenciar os segmentos que compõem a indústria de papéis no Brasil, já que os subgrupos de produtores das diferentes categorias de papéis apresentam evoluções e estruturas distintas ao longo do tempo, como já mostrado pelo trabalho de Carraza e Bacha (2004). Além disso, como diferencial entre as bibliografias já encontradas, o presente estudo busca valorar os elos envolvidos nas subcadeias da indústria de papéis no Brasil, considerando um período de tempo e uma desagregação maior do que fez o trabalho de Aranha (2010), a fim de identificar o elo que mais acrescenta valor ao produto final. 
Dentro desse contexto, o objetivo geral deste trabalho é analisar as evoluções e as estruturas de mercado distintas dos segmentos que compõem a indústria de papel no Brasil. Esses segmentos compõem-se das empresas produtoras de papéis de imprimir e escrever, das empresas produtoras de papel-imprensa (no Brasil, só existe uma empresa produtora de papel de imprensa), das empresas produtoras de papéis de embalagens, das empresas produtoras de papéis-cartão e das empresas que produzem papéis-sanitários. Os objetivos específicos são: caracterizar e diferenciar os segmentos que compõem a indústria de papéis no Brasil, destacando seus produtores, compradores, índices de concentração, barreiras à entrada e a fixação de preços em cada um desses segmentos e também valorar os elos da subcadeia de papéis de imprimir e escrever para os quais há dados para essa valoração.

A presente pesquisa está organizada em quatro seções. A seção 2 apresenta 0 referencial teórico e metodológico a ser utilizado. A seção 3 expõe os resultados e a seção 4 apresenta as considerações finais dos autores.

\section{Referencial teórico-metodológico}

O presente trabalho faz uso da abordagem tradicional conhecida como paradigma estrutura-conduta-desempenho (ECD). Tal paradigma considera que quanto mais concentrado for o mercado, maior será a possibilidade de conluio entre as firmas, uma vez que as firmas detentoras de maior poder de mercado podem ter incentivos a impor preços a serem praticados e, assim, alcançar margens de lucros maiores.

Conforme Scherer e Ross (1990), a estrutura depende das condições básicas de oferta e demanda por um produto e engloba elementos como o número de compradores e vendedores, diferenciação do produto, barreiras à entrada, estruturas de custos, integração vertical e diversificação do produto. As políticas governamentais influenciam na estrutura, na conduta e, consequentemente, no desempenho de uma indústria por meio de taxas impostas e subsídios concedidos, regulamentação, leis antitruste, controle de preços, acordos internacionais de comércio e fornecimento de informações.

De acordo com Farina (2000), a estrutura de mercado da indústria segue a seguinte classificação: a) mercados competitivos: no qual o mercado é fragmentado, as firmas elaboram produto homogêneo, ou com baixa diferenciação, e há ausência de barreiras técnicas de entrada de novas firmas; b) oligopólios concentrados: nos quais há elevada concentração, com firmas elaborando produto homogêneo ou de baixa diferenciação, e elevadas barreiras técnicas à entrada de novas firmas; c) 
oligopólios diferenciados: nos quais há elevada concentração, com firmas elaborando produto diferenciado, reforçando barreiras técnicas à entrada de novas firmas; d) oligopólios competitivos: no qual há alta concentração, com presença de franja competitiva (ou seja, grande número de firmas médias e pequenas), com firmas elaborando produtos diferenciados; e) monopólios naturais: em geral associados a serviços de utilidade pública, como distribuição de água, energia, redes de esgoto.

Leite (1998), baseado na leitura de Joe Bain, classifica o grau de concentração de uma indústria de acordo com os valores de CR4 e CR8 da indústria, conforme Quadro 1. De acordo com os dados do quadro, o grau de concentração varia de baixo até muito alto. As denominações CR4 e CR8, também, são utilizadas por Scherer (1970) para designar a parcela do mercado controlada pelas quatro e oito maiores empresas, respectivamente.

Quadro 1 - Padrões de concentração na indústria

\begin{tabular}{|l|l|l|}
\hline $\begin{array}{c}\text { Percentual de mercado detido } \\
\text { pelas quatro maiores empresas }\end{array}$ & $\begin{array}{c}\text { Percentual de mercado detido } \\
\text { pelas oito maiores empresas }\end{array}$ & Grau de concentração \\
\hline $75 \%$ ou mais & $90 \%$ ou mais & Muito alto \\
$65 \%$ a $75 \%$ & $85 \%$ a $90 \%$ & Alto \\
$50 \%$ a $65 \%$ & $70 \%$ a $85 \%$ & Moderadamente alto \\
$35 \%$ a $50 \%$ & $45 \%$ a $70 \%$ & Moderadamente baixo \\
$35 \%$ ou menos & $45 \%$ ou menos & Baixo \\
\hline
\end{tabular}

Fonte: Leite (1998).

Outro ponto destacado pelo paradigma ECD refere-se à conduta. De acordo com esse paradigma, a conduta depende da estrutura do mercado relevante, e está relacionada aos seguintes elementos: estratégias de preço, produto e propaganda, pesquisa e inovação, investimentos, táticas legais e acordos. Outro elemento relacionado à abordagem ECD é o desempenho da indústria, que depende da conduta das empresas e abrange as variáveis eficiência alocativa e produtiva, qualidade do produto, lucros e avanços tecnológicos.

Da ECD, apenas os elementos que definem a estrutura de uma indústria serão considerados de modo a destacar as estruturas distintas existentes para os cinco segmentos da indústria de papéis a serem analisados.

Complementarmente ao paradigma ECD, o ferramental teórico da cadeia de valor também será utilizado. De acordo com Porter (1992), a cadeia de valor desagrega uma empresa em suas atividades estrategicamente relevantes, distintas física e tecnologicamente, interdependentes e que adicionam valor (criam valor 
adicionado) ao produto final. O desagregamento de atividades tem como propósito entender o comportamento dos custos de cada elo e identificar as oportunidades de reduzi-los e/ou de diferenciar os produtos, reduzir ameaças e possibilitar a elaboração de estratégias. A vantagem competitiva ocorre pela otimização e coordenação entre todas as atividades envolvidas no processo produtivo. Para Porter (1992), toda empresa é uma reunião de atividades que são executadas para projetar, produzir, comercializar, entregar e sustentar seu produto. Todas essas atividades podem ser representadas fazendo-se uso de uma cadeia de valores.

Entretanto, a literatura mostra que o conceito de cadeia de valor proposto por Porter (1992) é correto, porém incompleto. Shank e Govindarajan (1997) conceituaram a cadeia de valor para uma empresa de uma forma mais ampla do que a proposta por Porter (1992), considerando-a como o conjunto interligado de todas as atividades que criam valor, desde uma fonte básica de matérias-primas, passando por fornecedores de componentes, até a entrega do produto final nas mãos do consumidor. De acordo com Silva (2002), o Institute of Development Studies (IDS) (2001) aprimora o conceito de cadeia de valor, descrevendo-a do seguinte modo:

[...] a cadeia de valor descreve o alcance de todas as atividades que são exigidas para trazer um produto de sua concepção, a partir do seu desenho, alimentação de suas matérias-primas e produtos intermediários, seu marketing, sua distribuição e seu apoio para o consumidor final. Em outras palavras, a cadeia pode ser vista como a incorporação da produção, troca, distribuição e consumo do berço ao túmulo de um determinado produto ou serviço (SILVA, 2002, p. 51).

Rocha e Borinelli (2006), levando em consideração as lacunas dos conceitos de Porter (1992) e Shank e Govindarajan (1997), definiram a cadeia de valor como sendo uma sequência de atividades que se inicia com a origem dos recursos e vai até o descarte do produto pelo último consumidor. Segundo os autores, essa definição estende o conceito de cadeia de valor desde a origem primeira dos recursos até o último consumidor, pois, muitas vezes, os bens são passados adiante após o ciclo de vida útil econômica nas mãos de cada usuário, reciclador, etc., antes de serem destruídos. É importante, ainda, que a definição considere todos os recursos em geral: materiais, humanos, tecnológicos, informacionais, etc.

Com relação à importância da cadeia de valor para a compreensão da dinâmica setorial, bem como da dinâmica industrial de determinado segmento, o IDS (2001 apud SILVA, 2002) destaca que o estudo da cadeia de valor permite observar a empresa posicionada dentro do ambiente concorrencial ao qual ela faz parte, facilitando pesquisas e estudos sobre novas oportunidades que visem desenvolver aquela cadeia. Além disso, segundo Silva (2002), entender como essas cadeias de 
valores operam é muito importante para empresas de países em desenvolvimento e para os elaboradores de políticas públicas, já que a forma como as cadeias são estruturadas tem implicação para os novos competidores que tentam participar da cadeia e buscam desenvolver habilidades necessárias, competências e serviços de apoio.

Para o estudo da estrutura de mercado da indústria de papéis no Brasil serão analisados o grau de concentração e a desigualdade dessa indústria por meio dos seguintes índices: razão de concentração para as quatro maiores empresas (CR4) e o índice de Herfindahl-Hirschman, que mede tanto a participação como a desigualdade existente na indústria. Neste trabalho, o índice CR4 mostra a parcela da produção correspondente às quatro maiores empresas na indústria ou no mercado. O índice de Herfindahl-Hirschman (HHI) é calculado como sendo a soma das participações ao quadrado de cada empresa na indústria ou no mercado considerado. Segundo Carvalho e Bacha (2008), quanto maior é o HHI, mais elevada será a concentração entre as empresas e, portanto, menor é a concorrência entre elas. $\mathrm{O}$ HHI varia entre $1 / n$ e 1 (n é o número de empresas na indústria). O limite superior está associado ao caso extremo de monopólio, no qual uma única empresa existe na indústria (BOFF; RESENDE, 2002). Tem-se que quanto maior é a variância de tamanho das firmas, indicando distribuição mais ampla em torno da média, maior será o HHI, conforme Church e Ware (2000). Esses índices ${ }^{6}$ serão calculados para a indústria como um todo e para os seus seis segmentos, isto é, considerando as seis diferentes categorias de papéis produzidos.

Além disso, pretende-se destacar as principais barreiras à entrada nessa indústria; as condições de oferta da matéria-prima; a existência de integração com as empresas ofertantes de matéria-prima; a fixação de preços e os principais consumidores dos produtos elaborados pela referida indústria.

Já a evolução da indústria de papéis será analisada em termos de evolução das exportações e das importações e do market share no mercado mundial. Ao longo do texto, serão mostradas tabelas ou gráficos considerando a indústria como um todo, bem como a indústria subdividida por segmentos segundo o tipo de papel que elabora.

A Figura 1 mostra o fluxograma da cadeia produtiva do papel, dando destaque aos segmentos de papéis de imprimir e escrever. Somente esse segmento da indústria de papéis no Brasil será analisado para valoração de seus elos devido à disponibilidade de dados. A cadeia é avaliada com dados mensais de 2010 a 2011. 
Figura 1 - Fluxograma da cadeia de valor do segmento de papel de imprimir e escrever

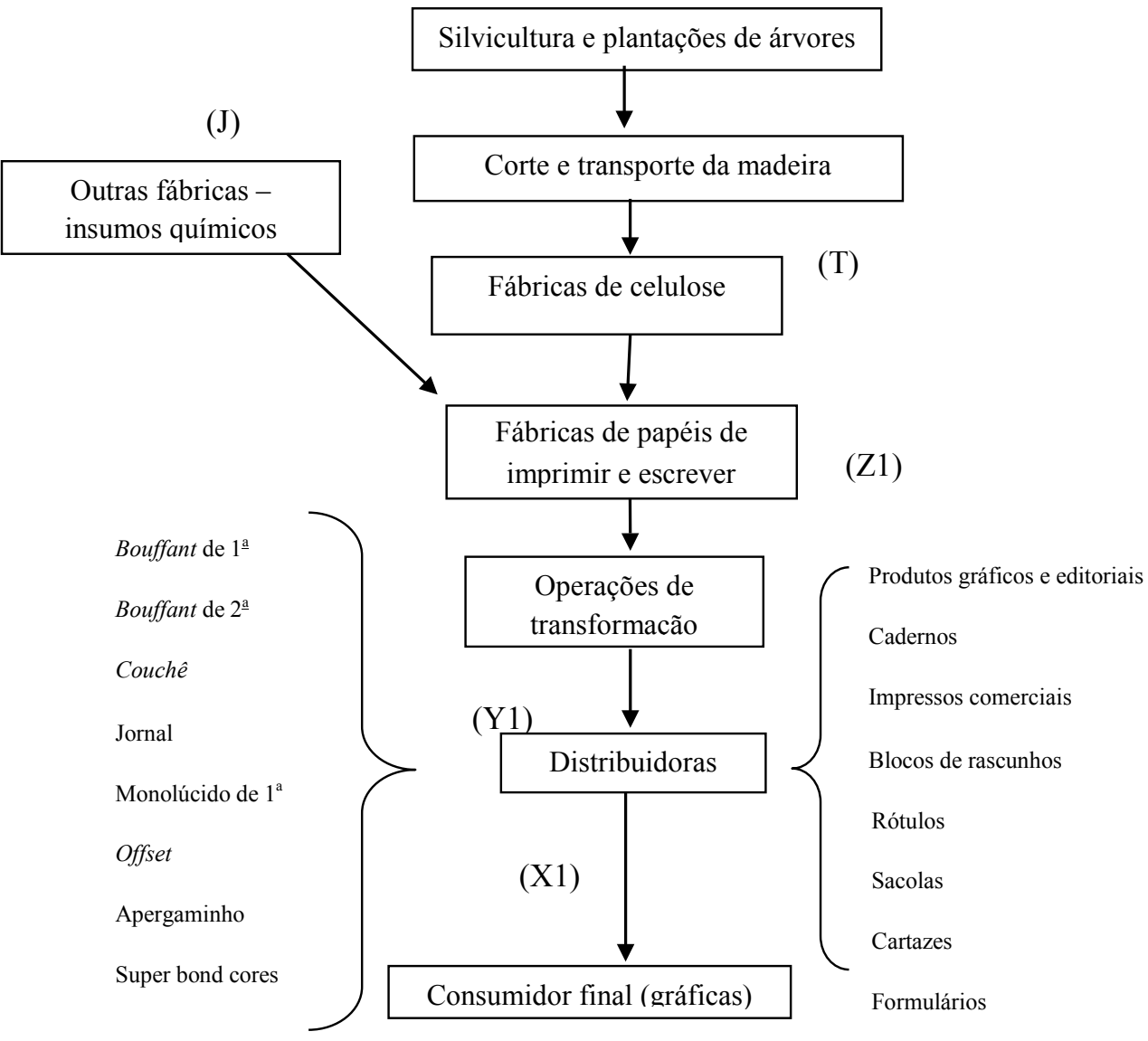

Fonte: elaboração dos autores.

Os elos que compõem a subcadeia dos segmentos de papéis de imprimir e escrever são: fábricas de celulose, representadas pela letra T, que vendem o seu produto para Z1; fábricas de papéis de imprimir e escrever, representadas por Z1, que produzem papéis-bíblia, bouffant de $1^{\underline{a}}$, bouffant de $2^{-}$, couché, jornal, monolúcido de $1^{\text {a }}$ e offset, apergaminhado, super bond e segundas vias. As fábricas podem ser integradas verticalmente com as fábricas de celulose e com as distribuidoras. Outras fábricas que fornecem demais insumos para a produção de papéis de imprimir e escrever e para produção de papéis de embalagem são representadas pela letra $\mathrm{J}$, as distribuidoras de papéis de imprimir e escrever são representadas por Y1, que podem ser ou não integradas com as fábricas de papéis, e o consumidor final 
é representado por $\mathrm{X} 1$, correspondendo às gráficas de papéis, que especificam os produtos de acordo com a futura utilização pelos consumidores finais no varejo.

A valoração dos elos é feita por meio da média dos preços cotados pelo Grupo Economia Florestal/Cepea/Esalq-USP e publicados na revista $O$ Papel. As informações técnicas sobre produção de papéis identificam, assim, os elos J, T, Z1, Y1, e X1, em que:

(T) / (X1): é o percentual agregado na fábrica de celulose em relação aos preços pagos pelos consumidores finais do segmento de papéis de imprimir e escrever no varejo.

$(\mathrm{Z} 1-\mathrm{T}-\mathrm{J})$ / (X1): é o percentual agregado na fábrica de papéis de imprimir e escrever e demais fábricas fornecedoras de insumos em relação aos preços pagos pelos consumidores finais no varejo.

(Y1 - Z1) / (X1): é o percentual agregado na distribuidora em relação aos preços pagos pelos consumidores finais do segmento de papéis de imprimir e escrever no varejo.

(X1 - Y1) / (X1): é o percentual agregado na gráfica em relação aos preços pagos pelos consumidores finais de papéis de imprimir e escrever no varejo.

Este trabalho fará uso de dados secundários compatíveis com a metodologia proposta. Tais dados foram coletados dos relatórios estatísticos da Bracelpa, que oferecem estatísticas anuais, a partir de 1980, informações sobre a evolução histórica da produção agregada e por tipos de papéis, relação dos maiores fabricantes e suas participações, dados de exportação e importação brasileira de papéis e a distribuição geográfica dessa produção. Os dados secundários também foram coletados no site da FAO, que oferece informações sobre a quantidade produzida, a quantidade exportada e importada e o valor das exportações e importações de papéis para todos os países do mundo no período de 1961 a 2006.

Para a análise da cadeia de valor dos segmentos de papéis de imprimir e para o cálculo percentual do valor acrescido em cada elo são utilizados os valores médios de preços coletados na venda de celulose das fábricas produtoras, preços de venda da tonelada de papel cut size, nas distribuidoras e no varejo para o consumidor final de cut size. Essa análise é realizada apenas entre os meses de dezembro de $2011 \mathrm{e}$ janeiro de 2013, devido às informações estarem disponíveis apenas a partir de dezembro de 2011. Os preços domésticos foram obtidos do Grupo Economia Florestal do Cepea Esalq-USP, que faz o levantamento de preços mensais (preços mínimo, médio e máximo) em reais por tonelada dos papéis postos em São Paulo e os publica na revista $O$ Papel, da Associação Brasileira Técnica de Celulose e Papel (ABTCP). 


\section{Análise da evolução e da estrutura dos segmentos que compõe a indústria de papéis no Brasil}

No Brasil, em 2010, foram produzidas 9,8 milhões de toneladas de papéis. A Figura 2 traz a evolução da produção brasileira total por tipos de papéis no período de 1980 a 2010. Nesse período, a produção total de papéis no país cresceu, em média, $3,94 \%$ ao $\mathrm{ano}^{7}$. Isso se deve ao fato de que a demanda brasileira de papéis é crescente ao longo dos anos, seguindo o aumento do crescimento populacional e o aumento de renda da população. Pode-se observar, ainda na Figura 2, que o ritmo de crescimento da produção de papéis por categoria é diferente ao longo do tempo. Os papéis de embalagens apresentam tendência crescente ao longo do período considerado. No caso dos papéis de escrever, a produção é decrescente de 1980 a 1990, apresentando tendência crescente no período pós-abertura comercial. No caso do papel para impressão, observa-se queda significativa a partir da década de 1990.

Com base na Tabela 1, também é possível notar que a produção de papéis está concentrada em poucas empresas. As quatro maiores empresas produtoras de papéis em 2009 foram Klabin S.A., Suzano Papel e Celulose, International Paper e Fibria, que concentraram 41,4\% da produção em 2009. É possível observar que os índices de concentração CR4 e HHI sofreram oscilações de 1981 a 2009. De 1981 a 1990, a taxa de crescimento do índice de concentração CR4 para a indústria de papéis foi de 1,96\% ao ano; de 1990 a 2000, essa taxa passou para 1,25\%, e, de 2000 a 2009 , houve decréscimo de $1,31 \%$ ao ano. 
Figura 2 - Evolução da produção brasileira de papéis por categoria no período de 1980 a 2010

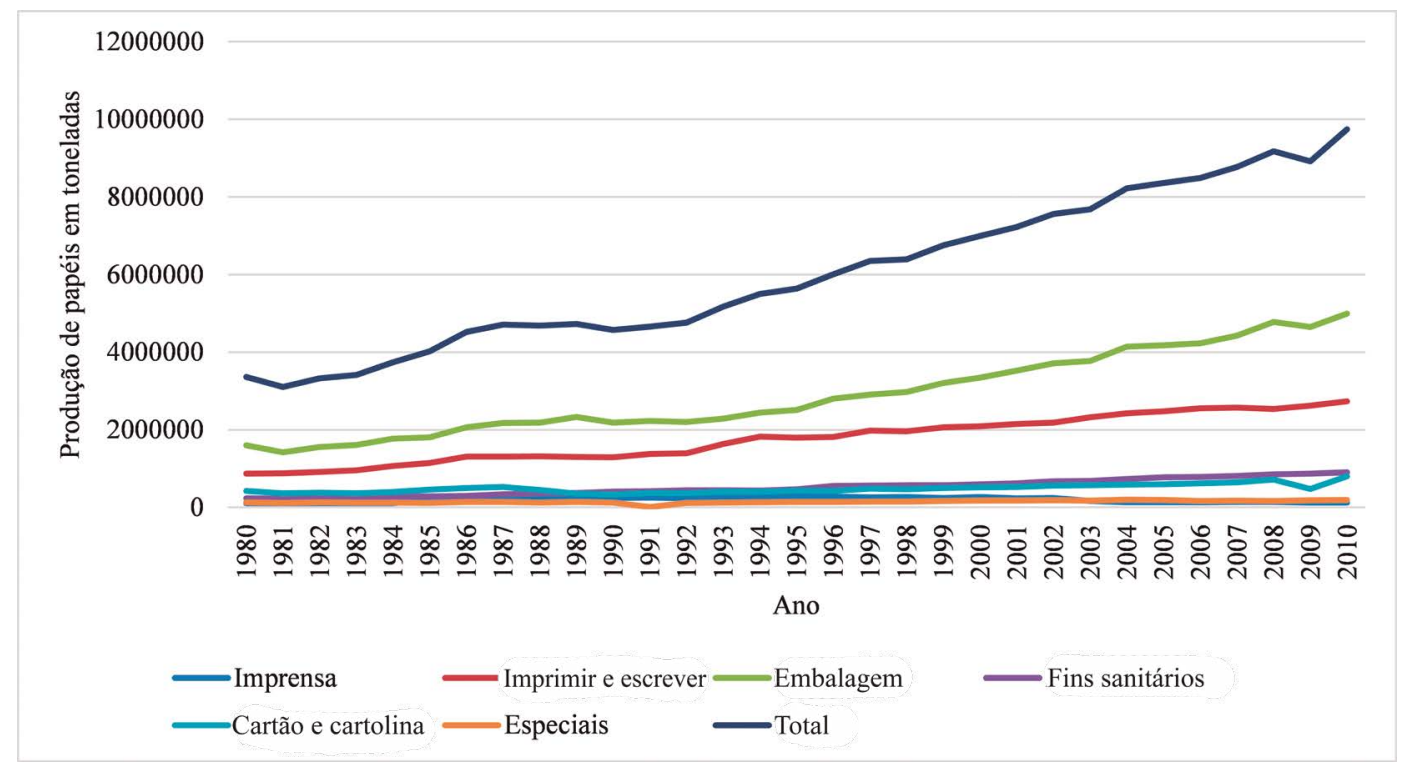

Fonte: elaboração dos autores com base na Bracelpa.

Tabela 1 - Produção e índices de concentração na indústria de papéis no Brasil nos anos selecionados*

\begin{tabular}{c|c|c|c}
\hline \multicolumn{1}{c|}{ Ano } & Produção & CR4 (\%) & HHI \\
\hline 1981 & 3.102 .614 & 29,71 & 0,297 \\
1985 & 4.021 .400 & 39,03 & 0,056 \\
1990 & 4.715 .791 & 36,00 & 0,055 \\
1995 & 5.798 .226 & 42,68 & 0,064 \\
2000 & 7.200 .132 & 45,43 & 0,073 \\
2005 & 8.597 .307 & 40,81 & 0,057 \\
2008 & 9.409 .450 & 41,20 & 0,058 \\
2009 & 9.428 .475 & 41,40 & 0,056 \\
\hline
\end{tabular}

Fonte: elaboração dos autores com dados da Associação Brasileira de Celulose e Papel.

* Para o cálculo dos índices de concentração, considerou-se como mercado relevante o destino da produção das dezenove maiores empresas de papel. O cálculo desses índices apresenta viés nos resultados, já que não se especificou o mercado relevante em termos geográficos e de produto. O mercado relevante considerado é em âmbito nacional. Assim, esses mercados foram considerados conjuntamente no cálculo do CR4 e do HHI. Essas limitações podem resultar em um CR4 subestimado ou superestimado, já que o cálculo do CR4, considerando todas as empresas é feito sem distinção do mercado relevante. 
No Brasil, seguindo essa tendência internacional, ao longo da década de 1990, o segmento de papéis realizou processos de fusões e aquisições entre os maiores produtores. Conforme Santos (2005), ocorreram as seguintes reestruturações: a associação da Klabin e do grupo norte-americano Kimberly-Clark Corporation, com a finalidade de instalar uma fábrica de papéis descartáveis na Argentina, a compra da Papel Simão e da Celpav pela Votorantim, e a compra da Indústria de Papel Arapoti S/A (Inpacel) e da Bamerindus Agroflorestal (BAF) pela Champion.

Conforme mostrado por Montebello (2010), o setor de celulose e papel no Brasil seguiu, praticamente durante toda a década de 1990, a tendência mundial de concentração produtiva e de reestruturação patrimonial por meio de fusões e aquisições. Esses processos de fusões e aquisições, realizados pelas empresas líderes no segmento, tiveram a finalidade de aumentar o grau de concentração da produção como estratégia para competir internacionalmente e diminuir os riscos de prejuízos devido às flutuações de preços.

Nos anos 2000, nota-se que as indústrias do setor de celulose e papel continuaram a sofrer constantes mudanças. A liberalização comercial, acelerada na década de 1990, continuou a transformar essas indústrias, tornando-as cada vez mais concentradas e dominadas por empresas com alta capacidade instalada. No entanto, o mesmo processo não ocorreu nas indústrias de papéis e de artefatos de papéis, nas quais as concentrações diminuíram. Isso ocorreu porque novas unidades foram construídas ou adquiridas (caso da International Paper) para atender ao mercado doméstico, apesar de poderem ter produtos de baixo valor agregado (como papéis de imprimir e embalagem) que podem ser exportados com vantagens comparativas de custos.

A distribuição da produção brasileira de papéis, em 2010, segundo dados da Bracelpa (2010), concentra-se na produção de dois segmentos, embalagem $(49,31 \%$ da produção total de papéis) e imprimir e escrever (27,82\%), seguido dos papéis para fins sanitários $(9,21 \%)$, papel-cartão $(7,93 \%)$, especiais $(2,03 \%)$ e imprensa $(1,35 \%)$.

Além da distribuição de papéis ser concentrada em poucos segmentos, ela também é concentrada em poucos tipos de papéis dentro desses segmentos. De acordo com os dados da Tabela 2, cinco tipos de papéis (offset, capa de 1aㅡ, miolo, couché e duplex) concentraram 68,96\% da produção no ano de 1981, 77,13\% em 1990, 86\% em 2000 e $85,97 \%$ em 2010. 
Tabela 2 - Produção de papel por tipos em toneladas e a participação (\%) de cada tipo de papel no total produzido de papéis no Brasil nos anos selecionados: 1981, 1990, 2000 e 2010

\begin{tabular}{|c|c|c|c|c|c|c|c|c|}
\hline \multirow{2}{*}{$\begin{array}{l}\text { Segmentos } \\
\text { Embalagem }\end{array}$} & \multicolumn{2}{|c|}{1981} & \multicolumn{2}{|c|}{1990} & \multicolumn{2}{|c|}{2000} & \multicolumn{2}{|c|}{2010} \\
\hline & Produção & Part. (\%) & Produção & Part. (\%) & Produção & Part. (\%) & Produção & Part. (\%) \\
\hline Miolo & 392.377 & 12,65 & 623.302 & 13,22 & 1.068 .195 & 14,86 & 1.518 .558 & 15,43 \\
\hline Capa de $1^{a}$ & 318.853 & 10,28 & 891.169 & 18,90 & 1.301 .579 & 18,11 & 1.654 .188 & 16,80 \\
\hline Capa de $2^{a}$ & 115.050 & 3,71 & 86.439 & 1,83 & 290.200 & 4,04 & 768.286 & 7,80 \\
\hline Kraft Natural & 314.865 & 10,15 & 330.734 & 7,01 & 326.222 & 4,54 & 402.637 & 4,09 \\
\hline \multicolumn{9}{|l|}{ Imprimir } \\
\hline Offset & 344.179 & 11,09 & 709.771 & 15,05 & 1.481 .563 & 20,61 & 2.116 .451 & 21,50 \\
\hline Couché & - & - & 79.329 & 1,68 & 439.821 & 6,12 & 444.281 & 4,51 \\
\hline Monolúcido de $1 \stackrel{\text { a }}{ }$. & 67.089 & 2,16 & 67.582 & 1,43 & 43.590 & 0,61 & 24.687 & 0,25 \\
\hline \multicolumn{9}{|l|}{ Escrever } \\
\hline Apergaminhado & 252.414 & 8,14 & 226.148 & 4,80 & 70.487 & 0,98 & 104.687 & 1,06 \\
\hline \multicolumn{9}{|l|}{ Cartão } \\
\hline Duplex & 209.186 & 6,74 & 292.494 & 6,20 & 418.883 & 5,83 & 628.683 & 6,39 \\
\hline \multicolumn{9}{|l|}{ Tissue } \\
\hline Higiênico Popular & 125.523 & 4,05 & 29.284 & 0,62 & 31.959 & 0,44 & 44.388 & 0,45 \\
\hline Higiênico especial & & - & 300.894 & 6,38 & 443.015 & 6,16 & 631.487 & 6,42 \\
\hline Imprensa & & & & & 266.179 & 3,70 & 124.123 & 1,26 \\
\hline Total & 3.102 .614 & 68,96 & 4.715 .791 & 77,13 & 7.187 .831 & 86,00 & 9.843 .747 & 85,97 \\
\hline
\end{tabular}

Fonte: elaboração dos autores com base em dados da Bracelpa, 2010.

Na Tabela 3 é possível verificar o total produzido de papéis por segmento, o número de empresas produtoras de papéis e os índices de concentração CR4 e HHI por categoria de papéis. Nota-se que, quando separado por segmento, o grau de concentração (medido pelo CR4) tende a aumentar. Por exemplo, para o total de papéis produzidos, o CR4 foi de 41,40\%, ou seja, os quatro maiores grupos produtores de papéis responderam por 41,40\% da produção nacional de papéis em 2009.

Observa-se nas Tabelas 3 e 4 que a concentração das quatro maiores empresas de papéis por segmento foi de 39,30\% para papéis-sanitários, 30,53\% para papéis-cartão, $31,64 \%$ para papéis de embalagem. No entanto, essas concentrações foram de $74,62 \%$ para papéis especiais, $68,16 \%$ para papéis de imprimir, 83,17\% para papéis de escrever e $100 \%$ para papel-imprensa. 
Tabela 3 - Índices de concentração (CR4 e HHI) para os segmentos de papéis de imprimir, escrever, embalagem, cartão, no Brasil nos anos selecionados - 1982, 1990, 2000 e 2009

\begin{tabular}{l|r|r|r|r|r|r|r|r}
\hline \multirow{2}{*}{ Ano } & \multicolumn{5}{|c|}{ Imprimir } & \multicolumn{4}{c}{ Escrever } \\
\cline { 2 - 9 } & Produção & Empresas & CR4 & \multicolumn{1}{c|}{ HHI } & Produção & Empresas & CR4 & \multicolumn{1}{c}{ HHI } \\
\hline 1982 & 733.971 & 25 & 63,56 & 0,12125 & 285.791 & 21 & 51,74 & 0,09057 \\
1990 & 931.531 & 30 & 67,72 & 0,1376935 & 357.732 & 18 & 62,4 & 0,1478929 \\
2000 & 1.992 .229 & 19 & 62,28 & 0,13139 & 100.403 & 14 & 53,26 & 0,10911 \\
2009 & 2.487 .788 & 15 & 68,16 & 0,15298 & 134.767 & 7 & 83,17 & 0,22150 \\
\hline & 1.554 .871 & 109 & 28,36 & 0,03445 & 377.124 & 60 & 47,23 & 0,08906 \\
1982 & 2.184 .300 & 112 & 29,64 & 0,03841 & 139.278 & 84 & 48,36 & 0,09121 \\
1990 & 3.347 .384 & 85 & 33,38 & 0,04072 & 204.064 & 47 & 42,89 & 0,07088 \\
2000 & 4.648 .749 & 78 & 31,64 & 0,03736 & 222.607 & 30 & 30,53 & 0,05211 \\
2009 & Embalagem & & & & Cartão & \\
\hline
\end{tabular}

Fonte: elaboração dos autores com dados da Bracelpa, 2010.

Nota: Para o cálculo dos índices de concentração CR4 e HHI, a variável utilizada foi a capacidade nominal instalada da produção por segmentos de papéis.

Tabela 4 - Índices de concentração (CR4 e HHI) para os segmentos de papéis-tissue (sanitários), especiais e imprensa no Brasil em anos selecionados - 1982, 1990, 2000 e 2009

\begin{tabular}{|c|c|c|c|c|c|c|c|c|}
\hline \multirow{2}{*}{ Ano } & \multicolumn{4}{|c|}{ Tissue } & \multicolumn{4}{|c|}{ Especiais } \\
\hline & Produção & Empresas & CR4 & $\mathrm{HHI}$ & Produção & Empresas & CR4 & $\mathrm{HHI}$ \\
\hline 1982 & 245.032 & 27 & 38,19 & 0,06478 & 131.777 & 23 & 40,11 & 0,0666 \\
\hline 1990 & 403.712 & 44 & 28,79 & 0,04153 & 122.078 & 20 & 40,76 & 0,0725 \\
\hline 2000 & 596.732 & 43 & 33,43 & 0,04789 & 173.552 & 16 & 63,14 & 0,1348 \\
\hline 2009 & 867.912 & 39 & 39,30 & 0,05731 & 191.294 & 12 & 74,62 & 0,1747 \\
\hline \multirow{2}{*}{ Ano } & \multicolumn{8}{|c|}{ Imprensa } \\
\hline & \multicolumn{4}{|c|}{ Produção } & \multicolumn{2}{|c|}{ Empresas } & CR4 & $\mathrm{HHI}$ \\
\hline 1982 & \multicolumn{4}{|c|}{ - } & \multicolumn{2}{|l|}{ - } & - & - \\
\hline 1990 & \multicolumn{4}{|c|}{246.400} & \multicolumn{2}{|c|}{1} & 100,00 & 1,00 \\
\hline 2000 & \multicolumn{4}{|c|}{266.179} & \multicolumn{2}{|c|}{1} & 100,00 & 1,00 \\
\hline 2009 & \multicolumn{4}{|c|}{127.494} & \multicolumn{2}{|l|}{1} & 100,00 & 1,00 \\
\hline
\end{tabular}

Fonte: elaboração dos autores com dados da Bracelpa, 2010. 
Observa-se, ainda, nas Tabelas 3 e 4, que o número de empresas produtoras de papel por seus segmentos nos anos selecionados foi reduzido. O número de empresas produtoras de papel de imprimir e de papel de escrever em 1982 foi, respectivamente, 25 e 21 e, em 2009, havia 7 e 15 empresas de papéis de imprimir e escrever, respectivamente. Ao mesmo tempo, a produção aumentou e os índices de concentração se elevaram. O CR4 e o HHI passaram de 63,56\% e 0,1212 , respectivamente, em 1980, para 67,72\% e 0,13769 em 1990, e atingiram $68,16 \%$ e 0,15298 , respectivamente, em 2009.

Conforme a classificação apresentada no Quadro 1, o segmento produtor de papéis de imprimir, escrever e especiais pode ser classificado como tendo alta concentração, mostrando que a estrutura da indústria nesses segmentos de papéis caracteriza-se como sendo um oligopólio. Já a indústria de papéis como um todo, considerando-se o valor do CR4 nesses mesmos anos, apresenta um grau de concentração moderadamente baixo.

De acordo com Montebello (2010), a abertura comercial brasileira e seus desdobramentos, ocasionaram modificações estruturais no setor de celulose e papel no Brasil na década de 1990. Vale destacar que, segundo Arbache e Corseuil (2001), esse processo de liberalização comercial, por um lado, foi diferenciado por indústria e, por outro, o grau de competitividade das firmas é heterogêneo dentro de uma mesma indústria. Dessa forma, muitas das reações ao processo de globalização podem ter atingido as indústrias de forma distinta bem como seus segmentos de forma diferenciada. Isso deve ter ocorrido com a indústria de papéis no Brasil.

Como pode ser deduzido, comparando-se os dados da Tabela 4 com a classificação do Quadro 1, o segmento da indústria produtor de papel-imprensa no Brasil pode ser caracterizado como sendo um monopólio. No entanto, o poder de mercado dessa única empresa em fixar preços pode ser limitado pela abertura comercial do país. Com a onda da globalização econômica, a liberalização do comércio e a internacionalização de investimento produtivo e financeiro, os mercados tornam-se mais contestáveis, já que eles ficam mais vulneráveis à entrada e à rivalidade de competidores potenciais, o que inibe possível exercício de poder de mercado das empresas. Tal cenário é válido para esse segmento, considerando a possibilidade de contestação no mercado por meio das importações.

Assim, apesar de existir uma única empresa fornecedora desse tipo de papel no Brasil, tal concentração não se reflete no poder de mercado nesse segmento, pois o volume importado ainda é muito grande, o que aumenta a contestabilidade nesse mercado, já que ele está sujeito à entrada de competidores internacionais. Isso 
inibe qualquer atitude unilateral de elevação de preço por parte da única empresa produtora de papel-imprensa no Brasil.

As Figuras 3 e 4 mostram a evolução das exportações e importações pelos segmentos que compõem a indústria de papéis no Brasil. É no segmento de papéis de imprimir e escrever que se observam os maiores volumes de exportação (52,60\% do total exportado de papéis pelo Brasil correspondeu à categoria de papéis de imprimir e escrever em 2010), seguido pelos papéis de embalagens $(28,11 \%$ do total exportado de papéis pelo Brasil em 2010). Os tipos de papéis do segmento de imprimir e escrever mais exportados pelo Brasil são os papéis não revestidos, que se dividem em cut size (papéis cortados e empacotados pelos fabricantes) e offset (formato em bobina).

Figura 3 - Exportação de papéis por seus segmentos no período de 1980 a 2010

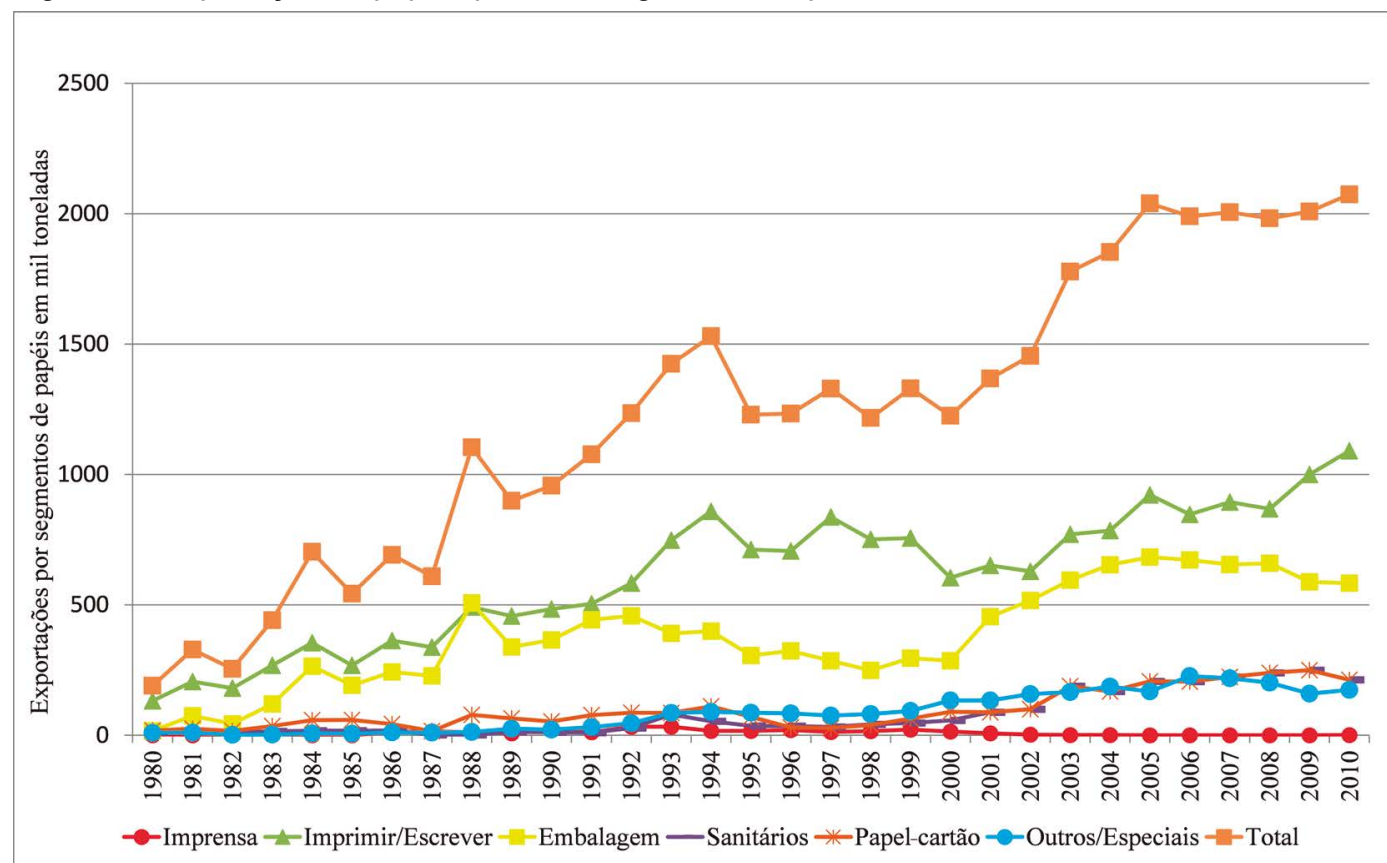

Fonte: elaboração dos autores com base em dados da Bracelpa, 2010. 
Figura 4 - Importação de papéis por seus segmentos no período de 1980 a 2010

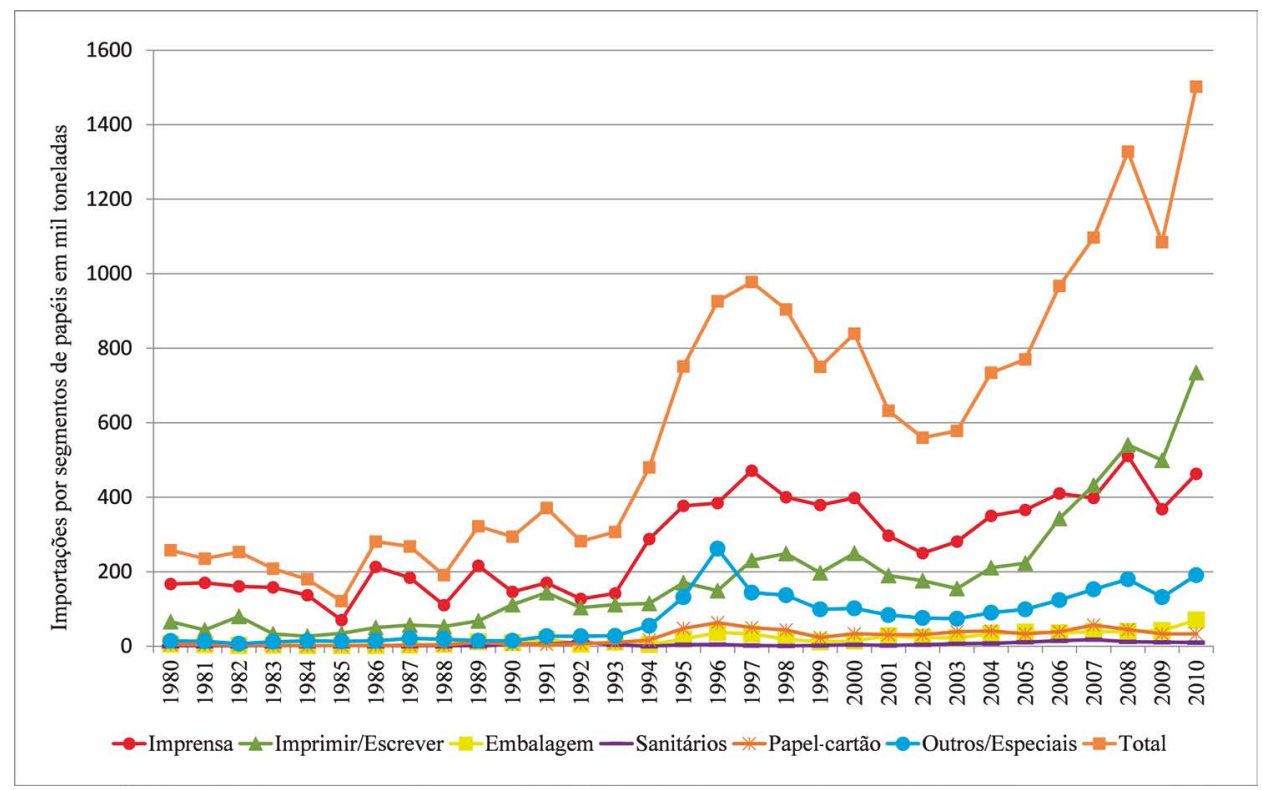

Fonte: elaboração dos autores com base em dados da Bracelpa, 2010.

No caso das importações de papéis pelo Brasil, é verificado na Figura 4 que o país importa em maior volume papel tipo imprensa. No segmento de papéis de imprensa, o Brasil é bastante dependente das importações (o país importa mais de $60 \%$ do seu consumo interno), uma vez que está em operação uma única empresa, desde 2002, produtora de papel-imprensa no país (a Norske Skog Pisa, localizada em Curitiba, no Paraná). As exportações brasileiras desses papéis são irrelevantes.

A unidade brasileira tem capacidade de produção de aproximadamente 180 mil toneladas de papel por ano e fornece para cerca de $30 \%$ do mercado nacional de publicações, dentre jornais, gráficas, listas telefônicas e outros. O restante é importado, sem tarifas. Isso inibe qualquer atitude unilateral de elevação de preço por parte da produtora de papel-imprensa no Brasil (Carrazza; Bacha, 2004).

É importante destacar o crescimento das importações de papéis de imprimir e escrever a partir de 2005, ultrapassando os volumes importados de papel-imprensa pelo Brasil em 2006. O Brasil importa principalmente o papel-couché (ver Tabela 5), uma das principais matérias-primas para a produção de revistas e folders. As oscilações da taxa de câmbio abriram espaço para o aumento da entrada das importações de papel-couché no país. Assim, a importação desse tipo de papel (usado na 
impressão de revistas) cresceu nos últimos anos, e os papéis de imprimir e escrever é o tipo mais importado pelo Brasil.

Em relação à fixação de preços de papéis no Brasil, sabe-se que os produtores divulgam um preço-lista (ou seja, um preço sugerido a ser praticado no mercado nacional sem descontos) e que, dependendo do tamanho do comprador (segundo o volume de toneladas comercializadas de papéis), são oferecidos descontos. Há empresas líderes que fixam o preço e seguem, como base, o preço do produto importável (cotado em reais) e considerando barreiras tarifárias.

De acordo com Montebello (2010), parte significativa da produção de papéis destina-se ao mercado doméstico e fica sujeita às oscilações do mercado interno. Entretanto, ao analisar o mercado de papéis no Brasil, pode-se notar que alguns segmentos de papéis apresentam dinâmicas distintas na fixação de seus preços. De acordo com dados do Sindicato da Indústria de Artefatos de Papel, Papelão e Cortiça do Estado do Rio de Janeiro (Sinpapel), ${ }^{8}$ o crescimento econômico do país, em boa parte impulsionado pela melhoria de renda das classes emergentes, tem assegurado um bom desempenho nos segmentos de papel-tissue (utilizado para fins sanitários) e de papel para embalagens.

Tabela 5 - Exportação e importação de papéis-offset, cut size e couché em toneladas, do segmento de imprimir e escrever - 2002 a 2011

\begin{tabular}{l|r|r|r|r|r|r}
\hline \multirow{2}{*}{ Ano } & \multicolumn{2}{|c|}{ offset } & \multicolumn{2}{c|}{ cut size } & \multicolumn{2}{c}{ couché } \\
\cline { 2 - 7 } & \multicolumn{1}{|c|}{ Exportação } & Importação & Exportação & \multicolumn{1}{c|}{ Importação } & \multicolumn{1}{c}{ Exportação } & \multicolumn{1}{c}{ Importação } \\
\hline 2002 & 33.195 .608 & 20.445 & 264.211 .738 & 49.304 & 1.035 .269 & 24.381 .046 \\
2003 & 145.501 .285 & 364.168 & 351.161 .122 & 155.701 & 2.827 .620 & 26.791 .191 \\
2004 & 122.601 .982 & 291.878 & 387.556 .597 & 966.791 & 6.732 .043 & 30.035 .781 \\
2005 & 165.166 .978 & 84.818 & 393.187 .821 & 2.297 .229 & 9.445 .394 & 33.719 .864 \\
2006 & 139.566 .558 & 1.556 .334 & 368.793 .991 & 7.032 .278 & 5.314 .244 & 46.265 .658 \\
2007 & 188.521 .906 & 159.003 & 449.383 .459 & 19.139 .220 & 3.307 .053 & 60.257 .376 \\
2008 & 199.127 .048 & 141.819 & 453.571 .047 & 22.281 .013 & 7.099 .941 & 64.690 .073 \\
2009 & 228.582 .082 & 75.371 & 551.732 .288 & 21.523 .659 & 10.426 .037 & 50.584 .092 \\
2010 & 231.524 .735 & 416.756 & 633.266 .366 & 20.032 .785 & 10.868 .614 & 86.204 .731 \\
2011 & 232.222 .702 & 515.822 & 594.839 .441 & 19.691 .376 & 6.096 .507 & 81.602 .138 \\
\hline
\end{tabular}

Fonte: elaboração dos autores com base em dados do sistema AliceWeb (BRASIL, 2009).

Os mercados de papéis para embalagens e para fins sanitários acompanham a dinâmica da economia doméstica e, dessa forma, estão mais vinculados à mudança de hábito do consumo da população por produtos alimentícios que exigem cada vez mais o uso de embalagens industrializadas de papel. 
Já o segmento de papéis de imprimir e escrever vem sofrendo concorrência do produto importado e do desvio do papel imune, ou seja, papéis que se beneficiam do incentivo fiscal previsto para livros didáticos, mas que, ao final, são desviados para outro uso comercial, constituindo concorrência desleal. O papel-offset, dentro dessa categoria de papel de imprimir e escrever, é o que mais sente o impacto da concorrência internacional. No caso do segmento de papel-imprensa, apesar de a indústria de papel caracterizar-se como um monopólio, o poder de mercado da única empresa produtora em fixar preços é limitado pela abertura comercial do país.

No caso das barreiras à entrada, de acordo com Ouchi (2006), o setor de celulose e papel está ligado a uma atividade produtiva dependente de recursos naturais com grande potencial de impacto no meio ambiente e com longos ciclos de produção, frutos de investimentos de longo prazo de maturação. Portanto, pode-se concluir que, pela própria característica do setor, ele próprio inibe a entrada de novos concorrentes nesse mercado. Assim, o setor de celulose e papel apresenta fortes barreiras à entrada de novos competidores, em virtude da necessidade de altos investimentos e de uma área de ponta em pesquisa e desenvolvimento, especialmente florestal, ligada à melhoria genética por meio de seleção de espécies. De acordo com Montebello (2010), Damani (2004), assim como Lima et al. (2006), destaca-se que as plantas conjugadas economizam custos de energia e água envolvidos nessa etapa do processo produtivo, já que elas diminuem as despesas com o transporte da celulose seca para a planta industrial, dada a proximidade ao local onde é obtida a matéria-prima.

Pinho e Avellar (2002) destacam que as barreiras à entrada na fabricação de papel podem ser analisadas pelas escalas mínimas de produção. Elas diferem muito de acordo com o segmento de mercado, sendo muito elevadas para produtos padronizados amplamente consumidos, especialmente os papéis-imprensa, kraftliner para embalagens e offset do segmento de imprimir e escrever. Segundo os autores:

[...] neste último, por exemplo, a escala ótima é crescente e equivalia já em meados da década de 1990 à operação de uma máquina com $8 \mathrm{~m}$ de largura e capacidade de $250 \mathrm{mt} / \mathrm{ano}$ (MENDONÇA, 1997: 53), com investimento inicial de pelo menos US\$ 300 milhões. Em mercados de menor extensão absoluta, como aqueles reunidos na categoria "especiais", e/ ou nos quais as desvantagens logísticas de custo de transporte induzem a regionalização, caso do segmento de papéis sanitários, as escalas mínimas são bem menores, mas ainda assim muitas vezes relevantes. De acordo com MENDONÇA (1997: 27), a escala ótima na fabricação de tissue é de $60 \mathrm{mt} / \mathrm{ano}$ ( 2002, p. 3). 
Além dos aspectos técnicos que afetam o tamanho mínimo de operação das plantas, segundo Pinho e Avellar (2002), como a clientela consumidora de papéis em operações industriais - gráficas e fabricantes de embalagens e de artefatos de papel - é relativamente pulverizada, a montagem de estruturas de distribuição tem uma função fundamental na dinâmica competitiva. Havendo indivisibilidades em sua montagem, a operação dessas estruturas de distribuição beneficia-se de economias de escala e também de escopo, com o atendimento das necessidades dos clientes em linhas de produto complementares. Conforme os autores, duas das empresas líderes da indústria papeleira no Brasil, a Klabin e a Suzano, notabilizam-se pela força de sua estrutura de distribuição.

A diferenciação de produto também é outra fonte clássica de barreiras à entrada. Embora a variedade de tipos de papéis seja grande, quase todos os produtores estão estabelecidos no mercado há bastante tempo e detêm tecnologia de fabricação razoavelmente difundida. Assim, a fixação de marca é relevante naqueles segmentos que produzem bens de consumo: papéis-sanitários e cut size do segmento de papéis de imprimir e escrever. Quando o produto tem uso intermediário, Pinho e Avellar (2002) apontam que o atendimento às especificações técnicas ganha nitidamente importância, tornando-se cada vez mais rígida por conta da maior automação das gráficas e do serviço pós-venda.

\section{Valoração dos elos da subcadeia de papéis de imprimir e escrever no Brasil}

Segundo informações solicitadas à Associação Brasileira Técnica de Celulose e Papel (ABTCP), para cada tonelada de produção de papéis, 800 quilos correspondem à celulose e 200 quilos a aditivos (cola) e refiles (papéis originados do corte dos papéis e reutilizáveis).

Para cálculo percentual do valor acrescido em cada elo do fluxograma da cadeia produtiva de papel de imprimir e escrever, foram utilizados valores médios de preços coletados na venda de celulose das fábricas produtoras, preços de venda da tonelada de papel cut size (A4, gramatura $75 \mathrm{~g} / \mathrm{m}^{2}$ ) nas fábricas produtoras, nas distribuidoras e no varejo para o consumidor final de cut size. A Tabela 6 ilustra os resultados para o período de dezembro de 2011 a janeiro de 2013. 
Tabela 6 - Valoração dos elos da subcadeia de papéis de imprimir e escrever no Brasil

\begin{tabular}{l|c|c|c|c|r|r|r|r}
\hline \multicolumn{1}{c|}{ Mês } & $\mathrm{T}$ & $\mathrm{Z}$ & $\mathrm{Y}$ & $\mathrm{X}$ & $\mathrm{T} / \mathrm{X}$ & $(\mathrm{Z}-\mathrm{T}) / \mathrm{X}$ & $(\mathrm{Y}-\mathrm{Z}) / \mathrm{X}$ & $(\mathrm{X}-\mathrm{Y}) / \mathrm{X}$ \\
\hline dez./11 & $1.284,61$ & $3.019,26$ & $3.760,00$ & $3.990,00$ & 32,20 & 43,48 & 18,56 & 5,76 \\
jan./12 & $1.229,51$ & $3.053,90$ & $3.938,75$ & $4.180,00$ & 29,41 & 43,65 & 21,17 & 5,77 \\
fev./12 & $1.200,68$ & $3.048,12$ & $4.008,75$ & $4.260,00$ & 28,18 & 43,37 & 22,55 & 5,90 \\
mar./12 & $1.314,94$ & $3.084,50$ & $4.016,25$ & $4.290,00$ & 30,65 & 41,25 & 21,72 & 6,38 \\
abr./12 & $1.396,42$ & $3.142,23$ & $4.087,14$ & $4.380,00$ & 31,88 & 39,86 & 21,57 & 6,69 \\
maio/12 & $1.509,17$ & $3.163,59$ & $4.398,57$ & $4.790,00$ & 31,51 & 34,54 & 25,78 & 8,17 \\
jun./12 & $1.587,20$ & $3.192,45$ & $4.268,75$ & $4.730,00$ & 33,56 & 33,94 & 22,75 & 9,75 \\
jul./12 & $1.575,90$ & $3.192,45$ & $4.240,00$ & $4.780,00$ & 32,97 & 33,82 & 21,92 & 11,30 \\
ago./12 & $1.565,51$ & $3.192,45$ & $4.221,25$ & $4.780,00$ & 32,75 & 34,04 & 21,52 & 11,69 \\
set./12 & $1.547,23$ & $3.163,59$ & $4.350,00$ & $5.030,00$ & 30,76 & 32,13 & 23,59 & 13,52 \\
out./12 & $1.532,33$ & $3.163,59$ & $4.361,25$ & $5.030,00$ & 30,46 & 32,43 & 23,81 & 13,30 \\
nov./12 & $1.568,33$ & $3.163,59$ & $4.403,75$ & $5.030,00$ & 31,18 & 31,71 & 24,66 & 12,45 \\
dez./12 & $1.598,09$ & $3.178,28$ & $4.412,50$ & $5.030,00$ & 31,77 & 31,42 & 24,54 & 12,28 \\
jan./13 & $1.575,99$ & $3.192,97$ & $4.402,50$ & $5.030,00$ & 31,33 & 32,15 & 24,05 & 12,48 \\
\hline
\end{tabular}

Fonte: elaboração dos autores com base em dados do Grupo Economia Florestal Cepea/Esalq - USP.

Nota: os valores de T/X; (Z-T)/X; (Y-Z)/X; (X-Y)/X estão em percentuais, em que T corresponde às fábricas de celulose, $Z$ corresponde às fábricas de papéis de imprimir e escrever, $Y$ corresponde às distribuidoras de papéis de imprimir e escrever e $X$ às gráficas de papéis de imprimir e escrever. Destaca-se que o valor acrescido nas fábricas fornecedoras de insumos em relação aos consumidores finais no varejo não pode ser encontrado devido à falta de dados.

Conforme a Tabela 6, pode-se concluir que, em dezembro de 2012, o valor acrescido pela fábrica de celulose em relação aos consumidores finais no varejo; o valor acrescido na fábrica de papéis de imprimir e escrever, incluindo gastos não contabilizados de outros insumos, em relação aos consumidores finais; o valor acrescido na distribuidora em relação aos consumidores finais no varejo; e o valor acrescido nas gráficas em relação aos consumidores finais no varejo foi, respectivamente, $32,20 \% ; 43,48 \% ; 18,56 \%$ e $5,76 \%$. Esses mesmos percentuais foram, em janeiro de 2013, respectivamente, $31,33 \%$; $32,15 \% ; 24,05 \%$ e $12,48 \%$.

Pode-se verificar, também pela Tabela 6 , que as fábricas de papéis de imprimir e escrever representam, no período analisado, o elo de maior acréscimo de valor em relação aos preços pagos pelos consumidores finais dos papéis da subcadeia em análise.

\section{Considerações finais}

O presente artigo mostrou que a produção brasileira de papéis é concentrada no segmento de embalagens e de imprimir e escrever, seguido dos papéis para fins sanitários, papel-cartão e especiais e imprensa. Além disso, a produção doméstica de papéis também é concentrada em poucos tipos de papéis (offset, capa de 1aㅡ, miolo, couché e duplex, que concentraram $85,97 \%$ da produção total de papéis em 2010 ). 
Ao se analisar os índices de concentração da indústria de papéis por seus segmentos, foi verificado que os segmentos de papéis de imprimir, escrever e especiais puderam ser classificados, no período da análise, como de alta concentração, sendo que a estrutura desses segmentos de papéis caracteriza-se como sendo um oligopólio. Já a indústria de papéis como um todo apresentou um grau de concentração moderadamente baixo, podendo concluir que o processo de liberalização comercial afetou a indústria de papéis de forma distinta dos segmentos que a compõem.

As exportações de papéis pelo Brasil foram crescentes nos últimos trinta anos, sendo que o país exporta mais os papéis da categoria imprimir e escrever (principalmente do tipo offset e cut size). Já as importações de papéis são muito concentradas no segmento de papel-imprensa. Apesar da existência de uma única empresa produtora desse tipo de papel e da capacidade de produção ser baixa em relação à demanda no mercado nacional, a possível existência de elevação de preços próxima aos preços praticados em um monopólio é inviabilizada pela existência do produto importado no mercado nacional. Além disso, ao longo dos anos, notou-se o crescimento das importações de papéis revestidos, particularmente o couché. A maior demanda por esse tipo de papel e a valorização da taxa de câmbio explicam os volumes cada vez mais crescentes das importações desse tipo de papel.

As barreiras à entrada que existem no ramo da indústria de papéis no Brasil estão relacionadas à integração vertical, principalmente para trás, o que é uma tendência mundial, a fim de reduzir os custos de produção na obtenção da matéria-prima, a celulose. As escalas mínimas de produção de papéis também são significativas e diferem muito de acordo com os segmentos. Podem ser citadas também, como barreiras à entrada no ramo da indústria de papéis, as economias de escala e escopo no processo de distribuição dos seus produtos e a diferenciação desses. A maioria dos fabricantes de papéis já está no mercado há bastante tempo e já possui tecnologia de fabricação razoavelmente difundida.

O trabalho mostrou também que as fábricas de papéis de imprimir e escrever representam, no período analisado, o elo de maior acréscimo de valor em relação aos preços pagos pelos consumidores finais dos papéis da subcadeia em análise. Assim, maiores investimentos na capacidade produtiva e em tecnologia para fabricação de papéis, não revestidos e revestidos (que possuem maiores valores de mercado e são os mais importados no país), resultarão em maior produtividade e menor valor do produto final, o que visa atender à demanda interna e externa pelos produtos da subcadeia e aumentar a competitividade dos produtos brasileiros.

Os resultados mostrados evidenciam que as políticas e estratégias industriais devem não apenas ser diferenciadas por indústria, mas também considerar as diferenças internas a cada indústria. 


\title{
Evolution and differentiated structures of paper industry segments in Brazil - 1980 to 2010
}

\begin{abstract}
This paper aims to analyze the evolution and different structures of the segments that compose Brazilian paper industry, considering time period from 1980 through 2010. The paper also intends to measure each link inside the printing and writing paper chain. To reach both objectives, the research makes use of secondary data collected from the following sources: Brazilian Pulp and Paper Association (BRACELPA), Food and Agriculture Organization (FAO), Minister of Development, Industry and Foreign Trade (MDIC), and Forest Economics Group Cepea ESALQ-USP. The results generated allowed the determination of the differences among the paper industry segments and, therefore, suggests that industrial policies and strategies need to not only be distinguished by industry, but also need to consider industry internal differences.
\end{abstract}

Keywords: Paper industry in Brazil. Industrial organization. Value Chain.

\section{Evolución y estructuras diferenciadas de los segmentos de la industria del papel en Brasil - 1980 a 2010}

\section{Resumen}

El objetivo del estudio es analizar, en el período de 1980 a 2010, la evolución y diferentes estructuras que conforman la industria del papel en Brasil. Además, el estudio es destinado a evaluar las conexiones de la subcadena de papel para la impresión y para escribir. La investigación utiliza datos secundarios de las seguientes fuentes: Asociación Brasileña de Celulosa y Papel (BRACELPA), Organización de Comida y Agricultura (FAO), Ministerio de Fomento, Industria y Comercio Exterior (MDIC), y Grupo Economía Florestal Cepea ESALQ-USP. Los resultados generados permiten la determinación de las diferencias entre los segmentos de la industria y, con eso, sugiere que las políticas y estrategias industriales no sólo deben ser diferenciadas por la industria, pero también tener en cuenta las diferencias internas de cada industria.

Palabras clave: Industria de papel en Brasil. Organización industrial. Cadena de valor.

\section{Notas}

1 Disponível em: <http://www.bracelpa.org.br/bra2/?q=node/167>.

2 A polpa ou pasta celulósica é o principal insumo usado na fabricação de papel. Sua obtenção ocorre, principalmente, pela transformação da madeira por intermédio de diversos tipos de processos (químico, mecânico, mecanoquímico, quimimecânico, termomecânico e quimitermomecânico) com remoção total ou parcial da lignina. Essa última é a parte da composição vegetal que une as fibras celulósicas, aumentando 
a rigidez da parede celular vegetal, constituindo, juntamente com a celulose, a maior parte da madeira das árvores.

3 Disponível em: <http://www.bracelpa.org.br/bra2/?q=node/140>.

4 Na segunda metade dos anos 2000 há aumento do custo em dólar da celulose feita no Brasil oriundo, principalmente, da valorização do real frente ao dólar.

5 O sistema de organização fordista teve seu auge nas décadas de 1950 e 1960 e, a partir da década de 1970, entrou em declínio. As características desse sistema eram: produção em massa de uma série de bens manufaturados, os mercados eram homogêneos, mais intensamente dentro das fronteiras nacionais, ênfase na economia de escala e na integração vertical das empresas, havia elevada mecanização e especialização da produção, padrões rígidos e hierárquicos de organização do trabalho. Já o modelo de organização do trabalho pós-fordista surgiu com maior intensidade na década de 1980 com a crise do sistema fordista de produção. Os elementos centrais do pós-fordismo são: flexibilização organizacional, mobilidade de capital, taxas intensificadas de inovação comercial, tecnológica e organizacional, ênfase na diferenciação e no baixo custo.

6 Para o cálculo dos índices de concentração será considerado como mercado relevante o destino da produção das maiores empresas de papéis no Brasil por diferentes segmentos, seguindo o anuário estatístico da Bracelpa. Assim, pretende-se distinguir para cada tipo de papel, as maiores empresas produtoras, a parcela da produção destinada ao consumo próprio, a vendas externas e à importação.

7 As taxas geométricas de crescimento da produção foram estimadas usando a equação $\ln Y=a+b . t$, em que Y é o volume de produção, ln é o logaritmo neperiano e t é o tempo. A taxa geométrica anual de crescimento é o antilogaritmo de b.

8 Disponível em: <http://www.sinpapel.org.br/index.php?option=com_content\&task=view\&id=399\&Item $\mathrm{id}=1>$. Acesso em: 12 jan. 2014.

\section{Referências}

ARANHA, C. B. Evolução e estrutura da subcadeia de papéis de imprimir e escrever no Brasil. 2010. Monografia de conclusão de curso (Graduação em Ciências Econômicas) - Escola Superior de Agricultura Luiz de Queiroz, Universidade de São Paulo, Piracicaba, 2010.

ARBACHE, J. S.; CORSEUIL, C. H. Liberalização comercial e estruturas de emprego e salário. Texto para discussão, 801. Rio de Janeiro: IPEA, 2001. p. 1-14. Disponível em: <http://www.ipea. gov.br/pub/td/td_2001/td0801.pdf>. Acesso em: 2 mar. 2009.

BOFF, H.; RESENDE, M. Concentração Industrial. In: KUPFER, D.; HASENCLEVER, L. (Org.). Economia industrial: fundamentos teóricos e práticas no Brasil. Rio de Janeiro: Campus, 2002. p. 73-90.

BRACELPA. ASSOCIAÇÃO BRASILEIRA DE CELULOSE E PAPEL. Relatório estatístico da BRACELPA - 1982-2010. São Paulo, 2010. Disponível em: <http://bracelpa.org.br/bra2/index. php>. Acesso em: 20 mar. 2014.

BRASIL. Ministério do Desenvolvimento, Indústria e Comércio Exterior. Secretaria de Comércio Exterior. AliceWeb: Sistema de Análise das Informações de Comércio Exterior via Internet. 2009. Disponível em: <http://aliceweb.desenvolvimento.gov.br>. Acesso em: 28 jun. 2009.

CARRAZZA, L. C.; BACHA, C. J. C. Evolução, estrutura e desafios da indústria de papéis no Brasil: período de 1965 a 2000. In: CONGRESSO DA SOCIEDADE BRASILEIRA DE ECONOMIA E SOCIOLOGIA RURAL, 42, 2004, Cuiabá. Anais... Brasília: Sober, 2004. p. 1-14.

CARVALHO, T. H. de; BACHA, C. J. C. Análise da evolução da estrutura da siderurgia brasileira e do uso de carvão vegetal no período de 1980 a 2006. In: CONGRESSO DA SOCIEDADE BRASILEIRA DE ECONOMIA E SOCIOLOGIA RURAL, 46, 2008, Rio Branco. Anais... Brasília: Sober, 2008. p. 1-14.

Teoria e Evidência Econômica - Ano 21, n. 44, p. 96-125, jan./jun. 2015 
CHURCH, J.; WARE, R. Industrial organization: a strategic approach. New York: McGraaw Hill, 2000. $832 \mathrm{p}$.

DAMANI, P. Vertical integration in the american pulp and paper industry, 1970-2000. 2004. 52 p. Dissertation (Master of Science in the School of Economics) - Institute of Technology, Georgia, 2004. Disponível em: <http://smartech.gatech.edu/bitstream/1853/4989/1/damani_ pallavi_200407_MS.pdf>. Acesso em: 11 nov. 2007.

DAURA, S. P. Análise do setor de celulose e papel na era da globalização: um olhar sobre sua produção e mão-de-obra. 2004. 226 p. Tese (Doutorado em Ciências Sociais) - Universidade Estadual de Campinas, Campinas, 2004.

FAO. FOOD AND AGRICULTURE ORGANIZATION. Base de dados FAOSTAT. Disponível em: <http://www.fao.org>. Acesso em: 11 nov. 2007.

FARINA, E. M. M. Q. Organização industrial no agribusiness. In: ZYLBERSZTAJN, D.; NEVES, M. F. (Org.). Economia e gestão dos negócios agroalimentares. São Paulo: Pioneira, 2000. p. 39-57.

GRUPO ECONOMIA FLORESTAL CEPEA. Economia Florestal. Disponível em: <http://www. cepea.esalq.usp.br/florestal/?id_page=481>. Acesso em: 20 fev. 2011.

IDS. INSTITUTE OF DEVELOPMENT STUDIES. Value Chain studies. Disponível em: <http:// www.ids.ac.uk/ids/global/valchn.html>. Acesso em: nov. 2001.

ILO. INTERNATIONAL LABOUR ORGANIZATION. Globalization and sustainability: the forestry and wood industries on the move. Report for discussion at the Tripartite Meeting on the Social and Labour Dimensions of the Forestry and Wood Industries on the Move. Geneva, Apr. 2001. p. 1-122. Disponível em: <http://www.ilo.org/public/english/dialogue/sector/techmeet/ tmfwi01/tmfwir.pdf>. Acesso em: 20 jun. 2008.

LEITE, A. L. S. Concentração e desempenho competitivo no complexo industrial de papel e celulose 1987-1996. 1998. 99 p. Dissertação (Mestrado em Engenharia da Produção) - Programa de Pós Graduação em Engenharia de Produção, Universidade Federal de Santa Catarina, Florianópolis, 1998.

LIMA, G. B.; FILHO, P. T.; NEVES, M. F.; CARVALHO, D. T. Integração e Coordenação Vertical na Cadeia de Papel e Celulose: O Caso Votorantim (VCP). Ribeirão Preto, 2006. Disponível em: $<$ http://www.ead.fea.usp.br/Semead/9semead/resultado_semead/trabalhosPDF/143.pdf $>$. Acesso em: 13 nov. 2007.

MONTEBELLO, A. E. S. VIDEIRA, R. A. Análise da evolução da indústria de celulose no período de 1980 a 2005. 2006.114 p. Dissertação (Mestrado em Economia Aplicada) - Escola Superior de Agricultura Luiz de Queiroz, Universidade de São Paulo, 2006.

MONTEBELLO, A. E. S. Configuração, reestruturação e mercado de trabalho do setor de celulose e papel no Brasil. 2010. 178 p. Tese (Doutorado em Economia Aplicada) - Escola Superior de Agricultura Luiz de Queiroz, Universidade de São Paulo, Piracicaba, 2010.

OUCHI, H. C. Práticas de sustentabilidade corporativa no Brasil. 2006.87 p. Dissertação (Mestrado em Administração) - Instituto de Pós-Graduação em Administração, Universidade Federal do Rio de Janeiro, Rio de Janeiro, 2006. Disponível em: <http://www.ciflorestas.com.br/arquivos/ doc_praticas_12604.pdf>. Acesso em: 26 ago. 2009.

PINHO, M.; AVELLAR, A. P. M. Economias de escala, barreiras à entrada e concentração na indústria de celulose e papel. In: ENCONTRO NACIONAL DE ENGENHARIA DE PRODUÇÃO, 22, 2002, Curitiba. Anais... Rio de Janeiro: Abepro, 2002. p. 1-8.

Teoria e Evidência Econômica - Ano 21, n. 44, p. 96-125, jan./jun. 2015 
PORTER, M. E. Vantagem competitiva. Trad. E. M. P. Braga. Rio de Janeiro: Campus, 1992. 512 p.

ROCHA, W.; BORINELLI, M. L. Análise estratégica de cadeia de valor: um estudo exploratório do segmento indústria-varejo. In: CONGRESSO USP DE CONTROLADORIA E CONTABILIDADE, 6, 2006, São Paulo. Anais... São Paulo: FEA/USP, 2006. p. 1.448-1.463.

SANDE, J. B. Reestructuring and globalization of the forest industry: a review of trends, strategies and theories. World Forest Institute, Bergen, Mar. 2002. Disponível em: <http://wfi.worldforestrycenter.org/JBSande02nov1.pdf>. Acesso em: 14 jun. 2008.

SANTOS, G.V. dos. Globalização, Estratégias Gerenciais e Trabalhadores. 2005. 439 p. Tese (Doutorado em Ciências Sociais) - Universidade Estadual de Campinas, Campinas, 2005.

SCHERER, F. M. Industrial market structure and economic performance. Chicago: Rand Mc Nally College Publishing, 1970.

SCHERER, F. M.; ROSS, D. Industrial market structure and economic performance. 3. ed. Boston: Houghton Mifflin, 1990. 270 p.

SHANK, J. K.; GOVINDARAJAN, V. A revolução dos custos: como reinventar e redefinir sua estratégia de custos para vencer em mercados crescentemente competitivos. 2. ed. Rio de Janeiro: Campus, 1997. 341 p.

SILVA, C. L. Análise da cadeia de valor e elaboração de políticas industriais: o caso da indústria brasileira de papel de imprimir e escrever para exportação. In: CONGRESSO NACIONAL DE ENGENHARIA DA PRODUÇÃO, 23, 2003, Ouro Preto. Anais... Ouro Preto: Enegep, 2003. p. 1-8.

SILVA, C. L. Competitividade internacional da indústria de papel de imprimir e escrever brasileira sob a ótica da cadeia de valor. 2002. 270 p. Tese (Doutorado em Engenharia de Produção de Sistemas) - Programa de Pós Graduação em Engenharia de Produção, Universidade Federal de Santa Catarina, Santa Catarina, 2002. 